\title{
Editorial introduction, journal of economic inequality, June 2017
}

\author{
Frank Cowell ${ }^{1}$
}

Published online: 27 April 2017

(C) Springer Science+Business Media New York 2017

In this issue of the Journal, we have taken the unusual step of leading with a Review. However, Ravi Kanbur's piece is more than a conventional book review: it also pays appropriate tribute to Sir Tony Atkinson, the scholar whose pioneering research led to so much of the modern theoretical and empirical work in the field of economic inequality and who died on 1st January 2017.

The Journal will be acknowledging this pioneering research by publishing three special issues devoted to three subfields that were opened up through Tony Atkinson's great insight and hard work. We hope that the first of these three issues will appear in December 2017.

Frank Cowell, Editor in Chief

Frank Cowell

f.cowell@1se.ac.uk

1 London School of Economics and Political Science, London, England 